\title{
Unilateral facial nerve hypoplasia without evident facial palsy
}

\author{
Sofia Costa, ${ }_{1}^{1}$ Mafalda Cascais, ${ }^{02}$ Rui Pedro Pais, ${ }^{3}$ Filipe Palavra $^{3}$
}

${ }^{1}$ Hospital Pediatrico de Coimbra, Coimbra, Portugal ${ }^{2}$ Department of Pediatrics, Centro Hospitalar de Leiria, Leiria, Portugal

${ }^{3}$ Centro Hospitalar e Universitario de Coimbra EPE, Coimbra, Portugal

Correspondence to Dr Sofia Costa, sofiacosta89@hotmail.com

Accepted 12 March 2019

\section{DESCRIPTION}

A 2-year-old boy was referred to our neuropediatrics unit by his otorhinolaryngologist (ORL) for the evaluation of cranial nerves abnormalities found in a brain MRI previously obtained. He was born at a gestational age of 36 weeks, by a normal delivery, with the unremarkable Apgar score. With 2 months of age, parents started to notice some hearing difficulties. He was evaluated by an ORL and some tests were performed (auditory evoked potentials, otoacoustic emissions and tympanogram), which revealed no response on the right side. Then, an MRI was obtained and it revealed an apparent absence of the right facial nerve, also with no identifiable ipsilateral cochlear nerve. Despite that, the internal auditory canal (IAC), the labyrinthic segment of the facial canal and the facial colliculus were symmetrically present (figure 1 ). There were no abnormal signal emissions in the exit root of the facial nerve at the pons. Physical examination revealed a slight drooping of the lower eyelid on the right side and subtle flattening of the right nasolabial sulcus, the last one only remarkable in some specific movements (eating, crying and smiling) (figure 2).
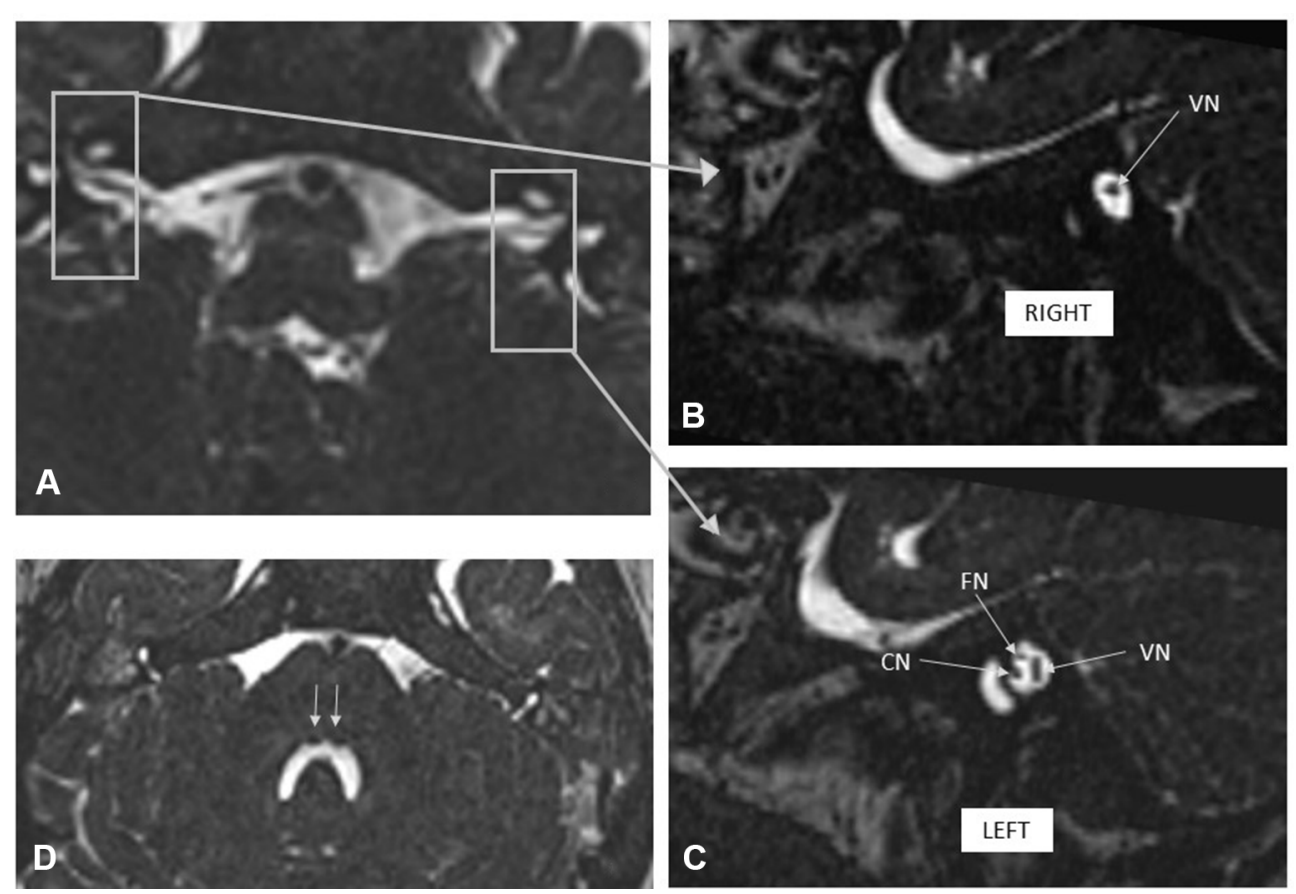

Figure 1 (A) Cranial MRI axial SPACE sequence showing the symmetric right and left IAC. (B) Right IAC, where only the vestibular nerve can be identified. (C) The cochlear, facial and vestibular nerves present in the left IAC. (D) Axial SPACE sequence at the level of the facial colliculus, showing the symmetry of this structure (white arrows). CN, cochlear nerve; FC, facial canal; FN, facial nerve; IAC, internal auditory canal; VN, vestibular nerve. 
cases. ${ }^{1}$ Both facial and vestibulocochlear nerves exit from the pontomedullary junction. MRI provides excellent images of the cisternal and intracanal segments of the facial nerve and the three divisions of the vestibulocochlear nerve: the superior vestibular, inferior vestibular and cochlear nerves. ${ }^{2}$ Facial nerve anomalies have been associated with hearing loss. Aplasia or stenosis of the IAC affects the intracanal portion of the facial nerve that accompanies the vestibulocochlear nerve. ${ }^{3}$

In our case, IAC has symmetrical dimensions and hearing loss is explained by cochlear nerve absence. We were not able to identify the right facial nerve in the MRI. However, the patient has only a discrete facial asymmetry, which makes unlikely facial

\section{Learning points}

- Facial nerve hypoplasia can result only in a discrete facial asymmetry.

- The association between facial nerve palsy and cochlear nerve anomalies is already established.

- Although facial nerve cannot be identified in the MRI, normal dimensions of the canal make unlikely facial nerve agenesis. nerve agenesis. For that reason, we assume that this patient has severe hypoplasia of the right facial nerve, which cannot be seen in the obtained images. Despite that, this boy has a mostly preserved facial mimic, defining a significant dissociation between clinical findings and radiological measures and making it different from other cases reported in the literature.

Contributors SC: responsible for writing the manuscript and prepare the images. MC: helped in writing the manuscript. RP: helped in choosing the images. FP: reviewed the manuscript and the images.

Funding The authors have not declared a specific grant for this research from any funding agency in the public, commercial or not-for-profit sectors.

Competing interests None declared.

Patient consent for publication Parental/guardian consent obtained.

Provenance and peer review Not commissioned; externally peer reviewed.

\section{REFERENCES}

1 Ozmen OA, Ozgen B, Ozmen S, et al. Congenital facial paralysis: facial nerve hypoplasia. Int Adv Otol 2010;6:282-4.

2 Glastonbury CM, Davidson HC, Harnsberger HR, et al. Imaging findings of cochlear nerve deficiency. AJNR Am J Neuroradiol 2002;23:635-43.

3 Hamizan AW, Yean KT, Abdullah A. Congenital bilateral facial nerve hypoplasia with sensorineural hearing loss: a case report. Int I Pediatr Otorhinolaryngol 2012;76:455-9.

Copyright 2019 BMJ Publishing Group. All rights reserved. For permission to reuse any of this content visit

https://www.bmj.com/company/products-services/rights-and-licensing/permissions/

BMJ Case Report Fellows may re-use this article for personal use and teaching without any further permission.

Become a Fellow of BMJ Case Reports today and you can:

- Submit as many cases as you like

- Enjoy fast sympathetic peer review and rapid publication of accepted articles

- Access all the published articles

- Re-use any of the published material for personal use and teaching without further permission

For information on Institutional Fellowships contact consortiasales@bmjgroup.com

Visit casereports.bmj.com for more articles like this and to become a Fellow 